\title{
REGIONALISM AND WORLD ORDER AFTER THE COLD WAR*
}

\author{
Richard FALK**
}

\section{Abstract}

This article assesses the actual and potential contributions of regionalism to the achievement of such world order goals as peace, social justice, human rights, democracy'. This assessment proceeds by way of discussing in an introductory section, several main features of the global setting that have become prominent in the early aftermath of the cold war. Against this background, four possible roles for regional actors are depicted: containing negative globalism (basically associated with the adverse impacts of global market forces); mitigating pathological anarchism (the breakdown of minimum order and decency in state/society relations arising from either extremes of excessive control and abuse by the state or of pervasive and dangerous chaos arising from the weakness or breakdown of governance capacity at the level of the state); promoting positive globalism (reinforcing the global capacity to achieve desirable world order goals); and promoting positive regionalism (achieving these goals at a regional level through the strengthening and orientation of regional structures of governance).

The intention here is to propose one type of research agenda with respect to the regional dimensions of world order. Necessarily, this effort is preliminary, focusing on issues of conceptualization and offering a broad normative perspective that differentiates what is negative (to be avoided or overcome) from what is positive (to be achieved or enhanced), but hopefully in a manner that usefully prefigures further and more detailed inquiny.

* I would like to thank Bjorn Hetine, and other members of the WIDER working group on regionalism, for their comments on an earlier draft in the course of a meeting in Berlin, August 20-23, 1994. I was also helped by the discussion that followed a presentation of the paper at a panel of the international Political Science Association meetings held on August 22, 1994 in Berlin, and especially by written comments from Olivier A.J. Brenninkmeyer.

A different version of this article is scheduled to be a chapter in a book on "the new regionalism" and world order being prepared under the auspices of WIDER/UNU in Helsinki, Finiand, a venture coordinated by Bjorn Hettine, Osvaldo Sunkel, and Andras Inotai.

* Professor of International Law, Princelon University, Center for International Studies.

1 For elaboration see Falk, A Study of Funre Worlds, New York: Free Press, 1975; Falk, Explorations at the Edge of Time: Prospects for World Order, Philadelphia, PA: Temple University Press, 1992; Fatk, On Humane Governance: Toward a New Global Politics, Cambridge, UK: Polity, 1995. 


\section{Background Considerations}

Of course, many of the fundamental tendencies reshaping world order are not primarily associated with cold war, especially the complex dynamics of globalization. However, the preoccupations of the cold war, its EastWest axis of interpretative logic, made it more difficult to appreciate the impact of globalization, including the various phenomena of backlash being generated. When the Berlin Wall wass breached in November 1989 this ultra-stable geopolitical scaffolding provided by bipolarity, especially with respect to Europe since World War II, disintegrated before our eyes. The immediate reaction was to exaggerate the discontinuity, neglecting underlying forces for change that were having a transforming impact in any event, such as weaponry of mass destruction, technological innovation, environmental decay, economic integration, a global communications net, with a cumulative effect of diminishing the finctional competence and normative self-sufficiency of sovereign states ${ }^{2}$.

The end of the cold war definitely encourages a greater emphasis on globalization, especially its human implications, and on such adverse reactions and contradictory trends as religious and ethnic extremism. How regionalism of varying attributes fits within globalization is a central world order concern for which evidence and interpretation is necessarily inconclusive. This uncertainty is magnified by the unevenness of different regional settings and of the varying degrees to which economic, political, and cultural life has been regionalized. Almost any generalization about regionalism seems suspect, and must be qualifield.

There is one important exception to these admonitions of conceptual caution. It is persuasive to claim that regionalism as a perspective in this historical period is a promising focus for both empirical and normative inquiry, that regionalism identifies emergent trends and structures and clarifies a distinct array of prescriptions and strategies. Following Bjorn Hettne's analysis, the provision of world order in the near future is no longer likely to be provided to nearly the extent, as during the cold war, by hegemonic state actors ${ }^{3}$; indeed, I would go further, contending that the weakening of the state, in general, is producing various adverse types of societal vulnerability to integrative tendencies in the global economy and is partly responsible for

2 The European focus of several early influential analyses of the end of the cold war reinforced these perceptions of discontinuity. See Jack Snyder. "Averting Anarchy in the New Europe, "Intemational Security 14:5-41 (1990); John Mearsheimer, "Back to the Future: Instability in Europe after the cold war, "International Security 14:5-56 (1990); on the problematics of sovereignty see Falk, "Sovereignty is dead! Long live sovereignty!" Harvard Intemational Review, forthcoming 1995.

3 Bjorn Hettne, "The New Regionalism: Implications for Development and Peace," UNU/WIDER, 1994, pp.4-5; see Gilpin, War and Change in World Politics, Cambridge University Press, 1981, for a clear presentation of hegemonic stability as the basis of world order, and of its erosion. 
the intensity and incidence of pathological forms of anarchy that are of a different character than the type of structural anarchy that Hedley Bull has so influentially depicted ${ }^{4}$.

Thus, the regional alternative to statism seems potentially compensatory, in terms of the quality of world order, in relation to both the erosion of hegemonic stability and the more acute forms of pathology that are afflicting the weak state. These background conditions are linked to the ending of the cold war, especially the collapse of bipolarity and the loss of a governance capacity to maintain order within bloc limits; also relevant is the inherently far more limited ordering role of unipolarity as a sequel to bipolarity. Unipolarity has not lived up to expectations. This partly results from the contemporary perception by political leaders of a greatly diminished domain of strategic interests, but also reflects the internal pressures being exerted by the citizenry on most government to address domestic priorities before responding to distant calls of concern, More concretely, the Gulf War epitomized the post-cold war perception of the persistence of hegemonic stability; after all, here was an hegemonic undertaking, that succeeded in instrumentalizing the UN in the process to a large exent, while of the same time giving rise to illusionary claims of "a new world order" legitimized through collective security mechanisms; since 1991 it has become evident that "the unipolar moment" was indeed of brief duration, and its idealistic embodiment in a serious commitment to collective security by way of the UN was quietly abondoned ${ }^{6}$.

Why were the crises in Somalia, Bosnia, Haiti, Rwanda, Zaire and Albania treated as so much less deserving of a global cumminity response than was the invasion of Kuwait? The paramount explanation is, of course, oil, but also the security threat posed by a militant Iraq, likely to possess nuclear weapons within years, to a strategic ally, namely Israel, as well as to a strategic region, the Middle East'. It is unlikely that the Gulf Crisis would have occurred in a bipolar world, the dynamics of mutual deterrence inducing greater prudence in relation to challenges directed al obvi-

4 See Bull, The Anarchical Society: A Study of Order in World Politics, New York: Columbia University Press, 1977; for assessments of post-statal world order see James N. Rosenau, Turbulence in World Politics: A Theory of Continuity and Change, Princelon University Press, 1990; Falk, The End of Wortd Order, New York: Holmes and Meier, 1983.

5 Consider George Bush's neo-Wilsonian rationale for resisting Iraq: "What is at stake is more than one small country. It is a big idea: a new world order where diverse nations are drawn together in common cause to achieve the universal aspirations of mankind-peace and security, freedom, and the rule of law." Quoted in The Round Table. Summer 1994, p. 5.

6 See Charles Krauthammer, "The Unipolar Moment," in Graham Allison and Gregory F. Treverton, eds., Rethinking America's Security, Now York: Norton, 1992, 295-306.

7 What made Israel "strategic" is somewhat elusive, but it was so perceived by Western leadership, especially in the United States, and reflected domestic pressures via Congress and the media, as well as calculations about stability in the Middle East. 
ous strategic interests, as well as more effective control by superpowers over the initiatives undertaken by secondary states such as Iraq. But it is also unlikely that the internal tensions in Bosnia and Somalia would have spiralled out of governmental control as each country was of strategic importance within a cold war setting, that is, warranting the expenditure of lives and resources by superpowers to maintain a given alignment and intra-bloc stability. At the same time, the causal significance of the cold war is by no means uniform with respect to the collapse of minimum internal order; Lebanon spiralled dangerously out of control in the decade following the outbreak of civil strife in 1975, and superpower intervention failed in the major test cases of Vietnam and Afghanistan. There is a temptation, in other words, to exaggerate the ordering achievements of bipolarity and deterrence during the cold war era. These achievements did seem considerable in Europe, but not necessarily elsewhere.

What is somewhat different, however, is the circumscribing of the domain of strategic interests on the part of intervening states in the North, particularly the United States. The outcome in Somalia, and even Haiti and Bosnia, has been widely regarded as a matter of virtual indifference, so long as the external effects of turmoil could be are minimized. These external effects are associated with "containment" in the post-cold war senses, that is, not discouraging the expansion of the rival superpower/ideology, but the spread of disorder and violence via a wider war (Bosnia) or the massive generation of refugees (Bosnia again, but Haiti more centrally where the prospects of even a relatively small number of black Haitian refugees coming to the United States was treated as strategically intolerable) ${ }^{9}$.

The UN has been reinstrumentalized since its moment of prominence in the Gulf during 1990-91, resuming its role as marginal player, while being somewhat unfairly accused of "failing." Unlike the cold war when faulire was explained as a consequence of a superpower stalemate, it is now more damagingly seen as the expression of a feeble "political will, by leading member states. Yet it is here that enhanced roles for regional actors seem plausible, this possibility being hinglighted, although

8 For instance, John Mearsheimer, "Why We Will Soon Miss the Cold War," The Atlantic, April 1990.

9 But nole that what was accepted by Washington for two years as tolerable was either the retum of a populist leader like Aristide or the stabilization of military rule provided the refugee problem is "handled," even if handling meant forcible repatriation, brutal means to discourage the outflow, and resettlement in already over-burdened countries in Central America and the Caribbean; in the background is the view that restoring democracy is not worth a single American life; also, from a progressive perspective US intervention has been coherently opposed see Joanne Landy, "Born-Again Interventionists," The Progressive, September 1994, p. 23; for a mainstream analysis of hegemonic caution see Michael Mandlebaum. "The Reluctance to Intervene," Foreign Policy 95: 3-18 (1994). For recent discussions of interventionary diplomacy that have taken account of the successful restoration to power of Aristide and a peacekeeping presence by US/UN forces see James Morrell, "Haiti: Success Under Fire," International Policy Report, Center for International Policy, Washington, D.C., Jan. 1995; Falk, "Haiti as a World Order Precedent," Harvard International Law Joumal, forthcoming 1995. 
ambiguously, by reliance on NATO in various roles since 1994 to curb the persisting excesses of the Bosnian Serbs and to carry out the Dayton Agreement. This NATO contribution is ambiguous as NATO had earlier floundered, and its temporary revival seemed to owe as much to the electoral success of Zhirinovsky in December 1993 (reminding Europe that the Russian bear might again prowl) as it did to the alleged moral shock of a mortar shell that killed civilians at a crowded market on a February day in Sarajevo two months later.

But security concerns are not the only world order context. The play of economic forces is at least as important even if not as visually captivating in a media sense. The transnational economic calculus is also being reshaped in contradictory ways by the ending of the cold war, above all by the weakening of alliance and bloc ties of bipolar variety as a result of the decline in global threat perception. Such a decline in globalization of security arrangements makes regional security and political economy foactors generally more significant, yet not at all in a uniform manner. This decline is offset in a contradictory manner by the rising globalization of the world economy, stimulating tactics for participation and protection, both types of reaction bearing on regionalist prospects in this period. The patterns of differing influences and perceptions bearing on the role of regionalism is complex and confusing.

Europe and Asia/Pacific are currently the critical arenas for assessing the world order roles of regionalist configurations. In Europe, the collapse of the blocs, the widening of Europe, has definitely slowed the deepening of the European Union, and has greatly complicated monetary union possibly deferred and indefinitely political integration. So many factors are at work that any definite causal inference will always seem argumentative and inconclusive. Yet there is an apparent contrast between Europe and Asia with respect to regionalist development. In Asia the US is not needed as much as during the cold war allowing economic priorities to gain precedence, especially being combined with new feelings of Asian cultural potency and identity ${ }^{10}$. Similarly, the US, no longer concerned with geopolitical alignment, is prepared to insist on more favorable trading and investment relations, creating special post-cold war tensions that invite a turn toward regional and bloc approaches. Whether this sets the stage for "the clash of civilizations" is doubtful, but it does shift economic and political concerns from the oid geopolitics of Wertphalia to the new geopolitics of inter-regional relationships as mediated by the Group of Seven (reconstituted at Naples in 1994 as the Group of Eight and at Denver in as the Summit of Eight, partially provisionally including Russia in their ranks)".

10 What is called "Asia's 'Asianization" "in a recent article. Yoichi Funabashi, "The Asianization of Asia," Foreign Aftairs 72:75-85 (1993).

11 Samuel P. Huntington, "The Clash of Civilizations?" Foreign Affairs 72:22-49 (1993). 
A focus on strategic considerations as explanatory ignores the complex and concealed politics of instrumentalization: who is instrumentalizing whom in relation to what? The Westphalian model of world order assumes that states are, more or less, the exclusive agents of instrumentalization. In a globalized world economy, states are themselves increasingly instrumentalized by concealed, external forces such as markets and profit margins, and their instrumentalization is expressed by way of the weakening of commitment to such foreign policy goals as human rights and environmental protection and to the reroutinization of tasks and capabilities entrusted to the United Nations. This reorientation of policy by states is accentuated by the weakening of organized labor as a domestic and transnational factor and by the discrediting of socialism (and its main operating modes) as a normative challenge to capitalism. Such an analysis supports an argument in favor of "resituating the state", that is, strengthening its capacity to mediate between market drives and populist social forces ${ }^{12}$. The relevance of regional actors is evident, but far from consistent or self-evident: what is most uncertain can be phrased by reference to the theme of instrumentalization. Formal regional structures are still being constituted overwhelmingly by state actors as members, but to what extent are the regional approaches being taken by states themselves as the unacknowledged secondary effects of their instrumentalization by the global marketplace ${ }^{13}$. Within regional frameworks, hegemonic relations of varying sort can be established, as seems the case with respect to Germany in Europe, and certainly on the part of the United States in the setting of NAFTA, and more generally, throughout the Western Hemisphere.

There are many dimensions of regionalism worthy of exploration and analysis at this time: four, in particular, seem to illuminate the character of the unfolding, yet still inchoate, post-cold war world order. In discussing these world order dimensions emphasis is placed on a distinction between "positive" and "negative" as pertaining to global and regional configurations of influence and authority. Positive refers to desired objectives such as the reduction of political violence, the attainment of economic wellbeing, the promotion of human rights and benevolent governance, the protection of ecological diversity and cultural identity, and the safeguarding of health and renewable resources. Negative refers to the negation of these goals by way of warfare, poverty, racism, ecological decay, oppression, chaos, criminality. In the lifeworld positive and negative aspects are intertwined, and a given set of conditions associated, say, with global market forces or authoritarian government may generate

For extended argument along the lines of this paragraph see Falk, "The Political Economy of World Order," Portrack Seminar Paper, June 1994.

13 A relevant datum here is the extent to which nominally socialist or welfare-oriented political leaders are led to adopt unconditional capitalist orientations once in power; Mitterand, Clinton, Mauryama are clear examples. 
positive, as well as negative outcomes. Economic growth, even if generating a nonsustainable consumerist ethos, may also be alleviating poverty and despair, as softer forms of authoritarianism, while cruel to its opponents, may nevertheless be providing effective leadership.

In the discussion that follows, for the sake of analytic clarity, this interplay of elements is put aside, and the discussion seeks to identify four world order concerns, two negative, two positive, that can be associated with the emergence of regional frameworks of political action alongside state and global frameworks.

(1) Clarifying the main links between regionalism and the "containment" of negative globalism; negative globalism refers here to the conjuncture of largely nonaccountable power and influence exerted by multinational corporations, transnational banks and financial arenas, and their collaborators espusing an ideology of consumerism and a development ethos weighted almost entirely toward returns on capital mainly achieved by maximizing growth (no matter how often qualified, yet predominantly rhetorically, by the modifier "sustainable"); in essence, the main regionalist tendencies are simultaneously both reinforcing this drift toward negative globalism and creating resistance and alternative mitigating options, including the promotion of positive globalism (that is, the democratizing of global institutions, creating accountability and responsiveness to more democratic social forces, and establishing procedures for wider participation by representatives of diverse peoples; also relevant here is the promotion of human rights, including economic and social rights, and a capability by the United Nations and other international institutions to contribute more effectively to global security than what is predicated upon a consensus among currently ascendent geopolitical and geoeconomic forces) ${ }^{14}$. It should be acknowledged that the neo-liberal ideology informing global market forces disseminates constructive ideas about freedom and the rule of law, as well as destructive notions about greed and materialism.

14 The distinction between negative and positive globalism is itself a reflection of recent developments, especially the globalist character of the world economy; earlier, globalism, at least on the surface, seemed motivated almost exclusively by idealistic ambitions to overcome war by creating effective mechanism of collective security, with the eventual objective being the achievement of a disarmed world administered by a government of federative structure, that is, a mixture of the Wilsonian effort to supplant the balance of power approach to stability and the more utopian pursuit of the Kantian notion of "perpetual peace." This latter notion has in its weak form resurfaced in the latter stages of the cold war, and subsequently, as achievable by the spread of market-oriented constitutionalism, premised on the argument that liberal democracies do not go to war with one another. See Michael Doyle, "Kant, Liberal Legacies, and Foreign Affairs," Philosophy and Public Affairs 12: 205-235, $323-353$ (1983); this positive globalism can also be crilicized as naive, hypocritical, insufficient. For classic treatment see E. H. Carr, The Twenty Years' Crisis: An introduction to the Study of International Relations, London: Macmillan, 1939; for a more recent argument applied to recent world developments see Henry Kissinger, Diplomacy, New York: Simon and Schuster, 1994, esp. 804-835. 
(2) Strengthening of regional frameworks to help meet the challenges being posed by several manifestations of pathological anarchism, that is, breakdowns of order associated with political normalcy and effective patterns of governance, leading to sustained violence that includes genocidal outbreaks and other crimes against humanity, as well as chaotic conditions producing massive displacements of people from their traditional places of residence ${ }^{15}$. These geopolitical "black holes" attract interventionary responses, but not of a reconstructive variety as the recent tragedies in Somalia, Liberia, Sudan, Bosnia, Rwanda, Zaire, and Sierra Leone illustrate in different ways; existing agencies of intervention, whether under auspices of leading states or the UN Security Council, have failed in both preventive and reactive modes, although some reductions of sulfering have been achieved to the extent the intervening mission is defined in purely relief terms ${ }^{16}$; can regional frameworks make selective contributions? under what circumstances? The failure of Europe in relation to Bosnia and less dramatically in Albania, has had the short-term effect of weakening regional sentiments, except possibly through reviving, at least temporarily, the postcold war fortunes of NATO ${ }^{17}$.

(3) Facilitating a renewal of positive globalism as a world order project through the medium of enhanced regionalism; the implications of (1) and (2) are essentially negative tendencies that can, to some extent, be diminished or redirected by certain forms of regionalization. Positive globalism conceives of a governance structure for the world that is of an aspirational character, one that promotes sustainability, human rights, development (especially in relation to poverty and other forms of deprivation), and demilitarization (reducing warfare, arms races and sales) ${ }^{18}$. Given concerns about homogenization, cultural diversity, and excessive centralization, the encouragement of stronger regional institutions might operate both as an alternative to and complement of positive globalism, thereby providing the peoples of the world with a new and plausible vision of a desirable world order.

(4) considering the normative achievements of regionalism in terms of its contributions to the wellbeing of the peoples living within its framework. This conception of positive regionalism as an end in itself is quite distinct from the evaluation of regionalism as a constituent element in a structure of global governance, and this pos-

15 See Human Development Report 1994 for an analysis of antecedent conditions.

16 See Thomas Weiss, "UN Responses in the former Yugoslavia: Moral and Operational Choices," Ethics and Intemational Affairs 8:1-21 (1994).

17 This revival must also be connected with the reappearance of a Fussian threat to Europe in the form of a more assertive foreign policy and by way of the rise of ultra-nationalist challenges to Yelisin's leadership (the Zhirinovsky factor).

18 For earlier lines of specification see Falk, A Study of Future Worlds, New York: Free Press, 1975; Falk, Explorations at the Edge of Time: Prospects for Wond Order, Temple University Press, 1992. 
sibility has been most fully explored, of course, in the setting of Europe, especially by the encounter between Eurocrats of various hue and Euroskeptics, but has relevance, as well, to visions of a better future in Africa, Latin America, and Asia ${ }^{19}$.

Against this background, the potential contributions of regionalism to an improved quality of world order will be explored, measuring improvement by reference to widely shared and explicitly specified world order values.

\section{Containing Negative Globalism via Regionalism}

Negative globalism refers to the adverse effects of economic and cultural integration at the global level. The integrative dynamic is not inherently negative, but it is having a series of adverse effects, given the current world order context. These effects include insensitivity to human suffering, insufficient attention to ecological sustainability, tendencies toward polarization (widening gaps between and within countries, and as among regions) and marginalization (virtual exclusion of countries, regions, ethnic minorities from developmental progress).

Negative globalism also instrumentalizes the state by mounting pressures on governments to conform to globalizing priorities that give political leaders little political space to pursue more equitable policies. States are coopted or subordinated, weakening their impulses as political actors to regulate the private sector on behalf of the common good. In this regard the world economy, considered as a totality, bears certain resemblances to the early capitalist period when market forces prevailed to the extent that labor was exploited in a variety of ways (long hours, low wages, unsafe conditions, no job security, no protection in old age or in the event of emergencies). At the state level social movements helped to create a better equilibrium between state and market, corporate and banking power being balanced to varying degrees by organized labor and by a socialist option. Of course, the evaluation of this equilibrium at every stage was controversial, diverse, dynamic, varying from country to country and over time.

The state in democratic societies mediated between market and social forces until this role was partially superseded by the imperatives of "competitiveness" in the wider settings of the regionalization and globalization of economic life. This process was complex and contextual, reflecting many factors, including the relative efficiency and productivity of labor force and managerial methods, the extent to which labor protection was entrenched at high wage and benefit levels, the degree to which competition for markets was being mounted by low wage societies, the overall impact of 1992. 
the Soviet collapse on the socialist option, the shifting class and ideological composition of civil society, and the strong influence of neo-liberal approaches to monetary and fiscal policy.

What seems beyond debate are two factors that underpin negative globalism:

- the successful resistance of market forces in relation to the establishment of global regulatory regimes that control market and banking practices through the application of an enforceable code of conduct; the elimination of the. UN Centre of Transnational Corporations in the late 1980s was an expression of the influence exerted by market forces within the United Nations; part of this sucess is associated with the instrumentalization of leading capitalist states, operating as agents of negative globalism, virtually taking the resistance option off the domestic political agenda despite its importance for the citizenry;

- the downward pull on wellbeing standards elsewhere exerted by the comprador market practices in the most dynamic sectors of the world economy, especially South Asia; this downward pull is accentuated by the increasing mobility of capital and by the relative failure of states with higher wellbeing standards to negotiate from strength and conviction. In other words, labor reforms in China, Indonesia, elsewhere, would reduce the incentives to relocate or invest on the basis of unevenness in the treatment of workers, thereby diminishing the downward pull on welfare and labor in countries with higher levels of business regulation. The issue is complex because unevenness in standards of living is being reduced by the capacity to increase exports from poorer countries, and may depend for a period on achieving competitiveness on the basis of lower production costs, especially labor.

Regionalism has not yet emerged as a counter to negative globalism. On the contrary, its main drive to date has been to facilitate more effective participation on a global level, either by adopting protectionist policies or by achieving export competitiveness. The impact of regional actors may result in some leveling down of wellbeing and environmental standards, at least on an intra-regional basis. Sweden to prepare for its participation in the European Union in the early 1990s has had to roll back aspects of its exemplary welfare system, reducing taxes, cutting some services. Regionalism has helped Europe aggregate capital and maintain technological parity with the United States and Japan, and therefore avoid the fate of moderate marginalization in relation to the globalized market.

In Asia/Pacific, although the experience varies from country to country, and over time, regionalism has been seen almost exclusively as a means to accelerate growth of trade and investment, avoid marginalization, and combine capital, resources, labor, and market without regard to statist boundaries. The "regionalism" of 
Asia, especially recently, has not been based on the whole region or even on whole countries, but on privileging high growth segments of society, leading to the emergence of so-called "regional states ${ }^{20}$. Of course, it is misleading to assimilate the reality of states in the full Westphalian sense into this terminology of regionalism. The analogy is suggestive, but only if critically assessed in terms of its actual properties of control over a territorial domain that encompasses a clearly demarcated region. The notion of state implies an effective governmental center, clear and generally accepted boundaries, a population that generally gives its allegence to existing political arrangements and a status that is accepted beyond the region in diplomatic relations. Europe, as the most developed region institutionally, has not yet clarified its boundaries: will Turkey be allowed to become a part of Europe? Surely, East European countries will be included in the emergent definition of Europe, but what of Russia and the Ukraine? And does "Europe" include the space of countries that remain formally autside the European Union as Switzerland and Norway have chosen to do?

The economic achievements of regional arrangements of different sorts are impressive in many respects, but not in relation to the containment of negative globalism, at least not yet. Indeed, the contrary conclusion is more illuminating, that regional formations, especially with respect to the three main trading/investing blocs, have served to consolidate the negative features of global economic integration. This consolidating role has been played out by removing economic policy from the realm of domestic politics, an aspect of weakening the state as a mediating actor between territorial concerns, especially of those being marginalized, and global market forces. It is confirmatory, as well, that regionalism has not taken hold in those settings that are being most marginalized by the world economy, and further that religious extremism in some Islamic countries, most notably Iran and the Sudan, has produced a partly voluntary, partly involuntary delinking from the world economy.

There are additional kinds of evidence. The efforts by the US Government in 1992-93 to build support in the citizenry for joining NAFTA was distinctively bipartisan at the level of elite politics. President Clinton was able to mobilize all five living presidents for the signing ceremony when the trealy was adopted, a stellar display of bipartisanship that would neither be possible (degree of consensus), nor necessary (extent of societal opposition) on any other issue of policy significance. Also, it seems

20 Kenichi Ohmae, an articulate champion of such regionalism, "Political leaders, however reluctantly, must adjust to the reality of economic regional reality if they are to nurture real economic flows." In effect, such leaders must subordinate claims on behalf of the marginalized sectors of their own societies: "Resistant governments will be left to reign over traditional political territories as all meaningful participation in the global economy migrates beyond their well-preserved frontiers." See Ohmae, "The Region State," Foreign Aftairs 72:78-87, at 85 (1992). 
anomalous that a president representing the Democratic Party would so unconditionally champion NAFTA, despite its Republican lineage, and given the hostile attitude of almost every labor union and of most liberal constituencies (environmental, church, social activist). But it is not a true anomaly. It is an expression of the instrumentalization of state power in the strongest of states in relation to the priorities of economic globalism. Such an assessment is confirmed by the timing of the Zapatista revolt of Mexican indians, centered in Chiapas, and planned to coincide with the effective date when NAFTA became operative - January 1, 1994 - expressing this awareness that economic regionalism and negative globalism were being reinforced at the expense of the most vulnerable ethnic and economic sectors of Mexican society.

Negative globalism is also, possibly preeminently, embodied in the WTO arrangements resulting from the Uruguay Round of GATT negotiations, which brought into being the institutional and political foundations for what has been described as the basis for an "economic autocracy" by its critics". Both the modes of negotiation, and the efforts to avoid full constitutional review, as would be appropriate if the latest GATT arrangements were regarded as a treaty requiring ratification, are expressive of this dynamic of instrumentalization. Within the United States the Executive Branch is most responsive, by and large, to these globalist pressures, while the Congress remains more influenced by local and territorial factors, more resistant as a result to the pure allure of non-territorial influences. Such a GATT framework, elevating the priority to be accorded unencumbered trade, also operates to ensure conformity at the regional level, making an electoral choice of social democracy almost impossible to implement in practice.

Labeling internal deformations of state power as "pathological" implies a conception of normalcy in the relations of state and society that has broken down; to associate this normalcy with the anarchy of international relations is to stress the structural point that institutions of global governance are very weak ${ }^{22}$. Pathological anarchism refers to acute political disorder: genocide, severe crimes against humanity, large-scale famine, substantial breakdowns of government.

In the long Westphalia period of international relations, pathological anarchism was essentially ignored unless the strategic interests of leading states were seriously

21 This paragraph owes much to a conversation with Ralph Nader, consumer activist, on August 5 , 1994; for range of views along these lines see collection of essays by Nader and others, The Case Against "Free Trade": GATT, NAFTA and the Globalization of Corporate Power, San Francisco: Earth Island Press, 1993.

22 See Aaymond Aron, "The Anarchic Pole of World Order," Daedalus, 1966; nole that this weakness may disappear under the aegis of negative globalism, which is, as argued in the prior section one of the features of the WTO dimension of the extension of GATT now under consideration. 
threatened. Such threats rarely were perceived unless the governmental actor in question embarked upon expansion at the expense of the existing distribution of power informing world order. The response to Nazi Germany and Stalinist Soviet Union are paradigmatic in both respects: appeasement or, at most, containment, with respect to the pathological behavior, but a geopolitical willingness to risk everything to prevent territorial expansions that seek to revise the hierarchy of relations that inform world order. It is not that the pathological dimension is irrelevant. Indeed, especially in relation to democratic societies, the pathological character of a rival is relied upon to mobilize resources and commitments needed to conduct warfare or to practice containment credibly.

The corollary point is that if the pathology does not pose external threats it will be tolerated ${ }^{23}$. This has been again demonstrated in the period since the end of the cold war in the much discussed instances of Somalia, Bosnia, Haiti, Rwanda and Zaire. Perhaps, the situation is more ambiguous: the historical memory of the Holocaust has encouraged the sentiment of "never again," particularly in Europe, and this has generated interventionary pressures in relation to Bosnia; the CNN factor selectively litts the veil of ignorance from the occurrence of acute distress, and induces public support for constructive responses; the entrenchment of human rights in international law has eroded the sovereignty arguments that abuses within states are of no concern externally. As a result, there have been responses to the recent instances of pathological anarchism, but of a half-hearted character as compared to the serious and credible response mounted to reverse Iraq's aggression against Kuwait. These responses, collaborations between the UN and leading states, especially the United States, have provided a measure of relief for elements of the afflicted populations, but have not challenged the core pathologies. What has been relied upon has been diplomacy, sanctions, relief operations, and pinprick assertions of military power. The sum of these efforts is less than its parts!

To the extent that responses have moved toward more serious levels of commitment it has resulted from boundary-transcending impacts: the prospects of a wider war in the Balkans, the outflow of refugees causing destabilizing effects in important state actors (US, Germany, France). These possible developments convert pathological anarchism into an occasion of strategic concern (justifying large allocations of resources and risks of loss of life), raising the stakes in the event that containment fails. Also, in relation to refugees the alternatives of repatriation or deterrence may both fail, leaving only the option of military intervention. Such an

23 There are some alleged exceptions by way of "humanilarian intervention," but none stand close scrutiny as real exceptions; for exposition see R.J. Vincent, Nonintervention and International Order, Princeton University Press, 1974, esp. 344-349. 
interpretation of the situation in Haiti during the Summer of 1994 led some commentators treat the intervention as "inevitable."

Enter regionalism; both states and the UN have failed to address pathological anarchism effectively. Could this failure be overcome, in some circumstances, by the empowerment of regional institutions? Could NATO act in the former Yugoslavia to challenge Serbian "aggression," restoring order and a unified, multi-ethnic Bosnia? Could the OAS bring constitutional democracy to Haiti? Could the OAU act in relation to Somalia, Rwanda, Burundi, Sudan, Liberia?

These questions return us to the theme of instrumentalization. To the extent that regional actors are effective in peacekeeping or peace enforcement it is because they are carrying out the policies of their leading members, states, especially, of course, hegemonic stales. And further, to the extent that these leading states have themselves been instrumentalized by negative globalism, there is not much prospect that the pathological challenges posed within an organized region will produce a response different in kind from that issuing forth from the global level. In essence, the conception of strategic interest will not be very different, except for its geographical and cultural proximateness. If regional capabilities include impressive military assets, then if strategic interests are deemed present, as has from time to time seemed weakly to be the case in relation to Bosnia, then the availability of NATO to act is definitely a potential factor in any move to challenge the core pathology. Nullifying this potentiality is the extent to which proximateness may fracture collaborative possibilities, each major state perceiving its interests in handling the crisis in a distinct manner and being distrustful of its rivals; such rivalry has been operative in relation to Bosnia from the outset, varying in intensity over time.

The major conclusion to be drawn is that regional communities have not evolved to the point where their institutional ethos or capabilities are sufficient to address pathological anarchism in a manner comparable to the efforts made by competent and constitutionally moderate states in relation to pathologies embedded within their own polities. States, too, are not always effective, sometimes accomodating, containing, collaborating, and sometimes being instrumentalized from below by the pathology or even succumb to the pathology by allowing its political vehicle to capture legitimate state power (as Hitler did in Germany, 1933). Can (should) regional actors be encouraged to take in these ordering tasks, especially the protection of those most victimized by pathological anarchism, as part of the mixture of a commitment to implement human rights and to maintain regional peace and justice? The dilemma posed here seems quite fundamental: to be effective and autonomous (that is, non-instrumentalized), regional institutions would have to become cohesive and capable of commanding loyalty, thereby coming to resemble in certain respects a state of Westphalian lineage, but such an evolution would seem likely on a global lev- 
el to stimulate inter-regional conflict among regions of greatly different resource bases and civilizational identities, making it more credible that "a clash of civilizations" would indeed ensue as the sequel to the Cold War.

\section{Promoting Positive Globalism}

There are two intersecting traditions at work: first, the anxiety that effective global governance cannot avoid encroachments on human freedom unless it avoids centralism; a regionalized world order is one approach to reconciling the quest for global governance with a corcern for constitutional equilibrium, and to a lesser extent with the preservation of cultural diversity ${ }^{24}$. The overriding goals in this outlook are so ambitious -transforming statism, ignoring globalization- in relation to the flow of events and horizons of aspiration, that little serious evalotion of this possibility has been under recent consideration in academic circles. A more moderate expression of this view is somewhat more influential in the form of an advocacy of "subsidiarity" via regional institutions as a way of allocating downward from the UN, particularly with respect to security issues, and thus in the context of delimiting the UN role. Such an approach, borrowing from the European experience, which evidently borrowed from a Vatican doctrinal tradition. Such a layering of institutional authority is meaningful, of course, only to the extent that meaningful regional institutions exist, which is not the case with the possible exception of Europe, and in extremely limited respects, Central and South America and Africa ${ }^{25}$.

The second approach here is to view regional institutions as complementary and subordinate tools of global governance, being shaped within the UN, contributing in various settings to either effectiveness or legitimacy, or some combination. The UN Charter in Chapter VIII seems to envisage such a relationship ${ }^{26}$. Since effective regional governance has so often in international history meant interventionary diplomacy by a hegemonic state, and thus geopolitics, it has been viewed with suspicion by those disposed toward more law-oriented modes of governance. The revival of practice and advocacy of spheres of influence is suggestive of a post-cold war pattern that acknowledges the failures of the UN in the setting of pathological an-

24 See proposals of University of Chicago under the aegis of Robert Hutchins. Hutchins and others, Preliminary Draft of a Wortd Constitution, University of Chicago Press, 1948.

25 For a sustained argument along these lines see W. Andy Knight, "Towards a Subsidiarity Model of Global Governance: Making Chapter VIII of the UN Charter Operational," paper presented at Annual Meeling of Academic Council of the United Nations System, The Hague, Netherlands, June 1994.

26 For support of this notion of a complementary relationship, as an aspect of an effective UN, see Boutros Boutros-Ghali, An Agenda for Peace, New York: United Nations, 1992, 35-38. 
archism, but it can hardly be properly identified as a variant of "positive globalism"." Conservatives give some credibility to the view that international institutions add elements of constitutional moderation to traditional modes of interventionism and discretionary geopolitics, conceiving of recourse to the UN or a regional actor as confusing, hypocritical, and superfluous ${ }^{28}$.

At this point, it is difficult to credit regionalism with being more than an occasional instrument for the assertion of hegemonic control that depending on circumstances can be viewed as either legitimated by collective procedures or not. The US intervention in Panama in 1989 was carried out despite the refusal to accord it legitimacy at either the regional or UN level, whereas the subsequent intervention in Haiti received both regional and UN blessings. There is some difference, yet in both contexts intervention is essentially an hegemonic initiative (shaped in Washington, with respect to time, goals, modalities, battlefield control).

Regionalism in relation to the emergence of positive globalism remains a latent potentiality. The Charter gives ample space for complementary regional roles in peacekeeping settings, and does in Article 52(3) express a favorable disposition toward resolution of disputes at a regional level, thereby seeming to endorse subsidiarity. Again, context matters; Castro's Cuba is under more intense hegemonic pressures as a regional pariah than it is in the UN setting ${ }^{29}$. It would seem that the virtues of regionalism in relation to positive globalism are, at present, mainly speculative. Its more serious relevance would arise as a derivation from the emergence of positive globalism, not currently in the offing.

\section{Promoting Positive Regionalism}

Regionalism has achieved positive results in relation to specified world order values in several substantive sectors and various geographic settings, most significantly, of course, in Europe, but also in Asia/Pacilic, Latin America, Africa, and the Middle East ${ }^{30}$. The most impressive of these achievement involve promotion of human rights, including revolutionary sovereignty-eroding procedures, as embodied in

27 Russia in "the near abroad," the US in most regions, but especially in the setting of Haiti and Central American policy, France in relation to Francophone Africa, especially Rwanda. See Kevin Fedarko, "Back to the USSR?", Time July 25, 1994, 40-43; an editorial. "Russian Interventions," Wall Street Jl., Aug. 8, 1994; Charles William Maynes, "A Workable Clinton Doctrine," Foreign Policy 93:3-20 (1993-94).

28 See assesment in the context of authorization for use of force to oust the Haitian military regime. Charles Krauthammer, "Goodbye, Monroe Doctrine," Washington Post, Aug. 2, 1994.

29 Compare South Africa in the apartheid period under comparable pressures at both regional and global levels.

30 See Hettne's overview in "The New Regionalism," note 3. 
the European framework, and to a lesser extent within the Inter-American setting ${ }^{31}$; mitigation and resolution of conflicts via diplomacy, mediation, and regional linkages; promotion of environmentalism; innovations in transnational cooperation and institutionalization; experimentation mandated by the Maastricht Treaty with innovative extensions of political identity in the form of a conferral of European citizenship ${ }^{32}$.

European regionalism has demonstrated that it is possible to extend the Rule of Law beyond the state, and often promote further human rights gains within generally democratic states by asserting grievances at a regional level. This has been impressively demonstrated with reference to the extension of gay and lesbian rights, which provides a model for other concerns, including the protection of resident refugees and foreigners generally ${ }^{33}$. There is a school of Eurocrat thought, that was articulated by Jacques Delors, that proceeding with further economic integration will depend upon making parallel moves to strengthen the political facets of the European Union, and that such a dual momentum needs to be maintained to consolidate the benefit of increased trade and investment.

Perhaps, most significantly, regionalism has protected the peoples of Europe against deteriorating standards of living, and the prospects of gradual marginalization. This protection has been somewhat controversial because of its tendency to build pressure by way of competitiveness to conform to the requirements imposed by negative globalism. The latter has contributed both to high levels of unemployment and to static, or even falling, real wagè levels in Europe and North America. An assessment is not a simple matter. To the degree that regionalism has been instrumentalized by negative globalism (as argued in 11 .), then it forms part of an overall global structure of dominance that is leading to acute marginalization for certain countries and regions, societ al sectors deemed inefficient and uninviting if considered either as producers or consumers. The geographic distribution has some North/South features, but the burdens of marginalization are not so neatly configured, given the rise of South and East Asia, and parts of South America. This disregard of marginalization is accentuated by the ideological consensus in support of neo-liberal economism in elite circles, and reinforced by the abandonment of socialist, welfare-oriented and Keynesian perspectives by even the leading Social Democratic parties in Europe.

31 See evaluation By David Held, Political Theory and the Modem State, Stanford University Press, 1989, esp. 214-242.

32 For asessment of these tendencies as pertaining to citizenship and political identity see Bart van Steenbergen, ed., The Condition of Citizenship, London: Sage, 1994; also trealy provisions reprinted under the rubric "A Citizen of the European Union," in Paul Barry Clarke, ed. Citizenship, London: Pluto, 1994, 188-190.

33 See L. Helfer, "Lesbian and Gay Rights as Human Rights: Strategies for a United Europe," 32 Virginia Jl. Int"l L 157 (1991). 
With respect to economic regionalization, the most important recent steps have involved Europe, North America, and Asia/Pacific. The cumulative impact on peoples within and outside these more integrated trading blocs is, as yet, conjectural and intensely contested. Whether the characterization "positive regionalism" is at all appropriate cannot be determined at this time until more evidence on effects has been gathered. A worst case assessment would suggest that regionalism is serving as a cover for the re-entrenchment of relations of privilege and domination that had been challenged during the revolt against colonialism. A best case scenario would attribute unevenness in benefits and burdens to the short-run, with a more equitable, sustainable, and democratic global economic order emerging in responses to grassroots and other challenges mounted against negative globalism.

In the Asia/Pacific region, the internal dimension of regionalism is to take early, mainly informal and ad hoc steps toward economic cooperation and coordination, viewing especially ASEAN as possessing a potential for expansion and further institutionalization in the post-cold war era. These steps are reinforced by a new Asian cultural assertiveness, which both moves toward the affirmation of a regional identity, but also represents a deepening of the decolonization process by its implicit repudiation of Eurocentricism.

In this regard, Asian/Pacific regionalism resists any renewal of Western hegemonic projects, and helps explain Asian unity with respect to opposing doctrines of humanitarian intervention to correct several abuses of human rights or to remove military rulers from power. As such, Asian/Pacific regionalism, even more than its European counterpart, may be moving toward limiting the Western, especially the United States role, thereby encouraging a defensive dimension of regionalism.

\section{A Concluding Note}

More particularistic inquiries may help to clarify the impact of regionalism on world order values. This paper has tried to conceptualize several main contexts in which regionalism has seemed dynamic in this post-cold war period, taking especial account of hegemonic passivity on a global level (the disappearance of strategic, zero-sum rivalry, inducing a shrinking of perceived strategic interests; a rising sense of domestic opposition, increased realization that power-projection is expensive and often inconclusive in relation to "black hole" challenges), of the disappointing capacity of the United Nations to provide a less hegemonic, yet still effective, world order, and of the overbearing reality of globalization with respect to markets, money, and information. Little ground for optimism has been found with respect to regionalism as either a counter-hegemonic democratizing influence or as a source of a new kind of benign hegemonic order (although the trend toward the reactivation of spheres of in- 
fluence is clearly evident in Russia's effort to provide leadership and exert control over the new states that were formerly Soviet republics; and by the United States in relation to the Western Hemisphere, especially Central America, through a reassertion of the Monroe Doctrine as an ingredient of foreign policy; and by France in relation to Francophonic countries in North and Sub-Saharan Africa).

From a world order perspective the role of regionalism is to help create a new equilibrium in politics that balances the protection of the vulnerable and the interests of humanity as a whole (including future generations) against the integrative, technological dynamic associated with globalism ${ }^{34}$. One kind of balance is being promoted by transnational social forces connected with human rights and the environment, but regionalism could be another. Both phenomena are, in part, reactions to the displacement of the state, from without and within, and the decline of sovereign territorial space as a domain of unconditional political control. Regionalism, if democratically conditioned, might yet provide, at least for some parts of the whole, a world order compromise between statism and globalism that has indispensable benefits for humanity, as well as some new dangers.

A recurrent theme of postmodern thought is the stress upon undecidability. The rational grasp of reality does not resolve difficult issues of choice. The cynical view is that such a circumstance ensures that interests will prevail, and there is support for such a reading of the times, particularly given the rise and spread of crime, even the danger that the gangster-coopted state may soon play a serious role in international life. A more hopeful view is that the tendencies toward democratization and human rights can be focused in the years ahead on the menaces of negative globalism and pathological anarchism, and that regional arenas will be important as sites of struggle, and as exemplifications of the play of opposed forces.

34 Heltne's formulation of "the proper balance" between such ideas and forces being "the crucial issue" does not explicitly signal any particular concern for those social and environmental elements of society that are being most vistimized by the phenomena of globalization, see note 3 , p. 5: possibly, this concern could be brought in by way of "regionalism and world order values," but the discussion as set forth, pp. 41-43, doesn't appear to address such ethical implications, at least not directly. 